\title{
Preliminary Investigation of Stream Sediments Contaminations Caused by Mining Activities in Ibodi and Its Environs, S/W Nigeria Using Geological and Geochemical Assessment Approach
}

\author{
A. I. Akintola ${ }^{1}$, P. R. Ikhane ${ }^{1}$, S. I. Bankole ${ }^{2} \&$ O. A. Mosebolatan ${ }^{1}$ \\ ${ }^{1}$ Department of Earth Sciences, Olabisi Onabanjo University, Nigeria \\ ${ }^{2}$ Geosciences Department University of Lagos, Akoka Lagos, Nigeria \\ Correspondence: A. I. Akintola, Department of Earth Sciences, Olabisi Onabanjo University, Nigeria. Tel: \\ 234-803-351-1485. Email: busayoakins@yahoo.com, a.i.akintola@student.utwente.nl
}

Received: June 21, 2014 Accepted: July 10, 2014 Online Published: August 21, 2014

doi:10.5539/enrr.v4n4p16 URL: http://dx.doi.org/10.5539/enrr.v4n4p16

\begin{abstract}
Mining and related activities are sources of heavy metal contamination in streams, such as copper, zinc, cadmium, arsenic and lead. The study is focused on Ibodi, southwestern Nigeria which is located in the basement complex of Nigeria and it is to assess the stream sediments of Ibodi in order to decipher the environmental impact assessment of mining activities on the environment. A total of ten stream sediment were collected from the study area and its environs along major tributaries, air dried at room temperature, sieved with 75 micron sized sieve and analyzed in the laboratory using ICP-MS (inductively couple plasma mass spectrometry technique). The analytical results of the major elements analyses show that Iron oxide $\left[\mathrm{Fe}_{2} \mathrm{O}_{3}\right]$ has the highest major element composition, value ranging from $2.36 \%-10.61 \%$ with an average value of $5.262 \%$. This highest concentration of Iron oxide was found in location 1 , with a value of $10.61 \%$ and this can be attributed to the underlying geology of amphibolites' in the Ibodi study area, which are known to be rich in Iron as well as magnesium i.e ferromagnesian minerals. Magnesium oxide $[\mathrm{MgO}]$ range in composition from $0.11 \%-0.92 \%$ with an average value of $0.349 \%$, the highest concentration was found in location $3 . \mathrm{Al}_{2} \mathrm{O}_{3}$ ] ranges in composition from $0.83 \%-4.158 \%$ with an average value of $2.109 \%$ the highest value was also found at location 3, it is the next in abundance to Iron oxide in the Ibodi study area. Potassium oxide $\left[\mathrm{K}_{2} \mathrm{O}\right]$ range in composition from $0.04 \%-0.65 \%$ with an average value of $0.183 \%$, other major oxides such as $\left[\mathrm{P}_{2} \mathrm{O}_{5}\right],\left[\mathrm{TiO}_{2}\right],\left[\mathrm{Na}_{2} \mathrm{O}\right]$ and $[\mathrm{CaO}]$ have average values of $0.109 \%, 0.096 \%, 0.008 \%$ and $0.162 \%$ respectively; These values are generally low within the Ibodi study area, The analytical results for trace element geochemistry of Ibodi study area show that Vanadium [V] has a high concentrations and it range from $35.00 \mathrm{ppm}-202.00 \mathrm{ppm}$ with an average mean value of $92.50 \mathrm{ppm}$, the highest concentration of this element was found in location 1 of the Ibodi study area. Arsenic [As] range from $0.10 \mathrm{ppm}-1.6 \mathrm{ppm}$ with an average value of $0.644 \mathrm{ppm}$, there is a significant enrichment of Cobalt [Co] and Chromium [Cr] with concentrations ranging from $4.0 \mathrm{ppm}-53.50 \mathrm{ppm}$ and $35.20 \mathrm{ppm}-150.70 \mathrm{ppm}$ respectively, with average mean values of $17.73 \mathrm{ppm}$ and 88.78 ppm respectively; Manganese [Mn] has the highest concentration in the study area, with concentration value ranging from $86.00 \mathrm{ppm}-2165.00 \mathrm{ppm}$ having an average value of $768.20 \mathrm{ppm}$; the highest concentration of this element was found in location 1 of the study area. [Ga], [Ni] and [Pb] show considerable enrichments within the study area with concentration values ranging from $3.10 \mathrm{ppm}-9.50 \mathrm{ppm}, 5.30 \mathrm{ppm}-37.70 \mathrm{ppm}$ and $6.75 \mathrm{ppm}-$ $18.44 \mathrm{ppm}$, with average values of $6.08 \mathrm{ppm}, 19.80 \mathrm{ppm}, 12.209 \mathrm{ppm}$ respectively, Rubidium [Rb] range in concentration from $6.50 \mathrm{ppm}-30.90 \mathrm{ppm}$ with an average value of $13.41 \mathrm{ppm}$, Strontium [Sr] has concentration values that range from $4.70 \mathrm{ppm}-37.20 \mathrm{ppm}$ with an average value of $15.06 \mathrm{ppm}$. [Y], [Zr] and [Zn] has concentration values that range from $7.99 \mathrm{ppm}-21.10 \mathrm{ppm}, 1.20 \mathrm{ppm}-4.00 \mathrm{ppm}$ and $26.20 \mathrm{ppm}-83.60 \mathrm{ppm}$ respectively with average mean values of $15.065 \mathrm{ppm}, 2.21 \mathrm{ppm}$ and $46.58 \mathrm{ppm}$, the value of zinc [ $\mathrm{Zn}$ ] is considerably high in the study area with the highest value found at location 4 of the study area indicating some level of enrichment of this metals within the study area, also [Rb], [Y] and [Sr] show some considerable enrichments within the study area. from the study of the environmental parameter such as box plot and Geo-accumulation indexes the values of the selected trace elements are all less than 1, meaning that all the selected trace metals in Ibodi study area have values less than zero and are in the negative zone. In order to determine the pollution status of the study area, the values of the elements when compared to the Muller classes of
\end{abstract}


geo-accumulation suggests that the study area is practically uncontaminated with the selected trace metals, the elements fall into the class 0 i.e. Practically unpolluted.

Keywords: zinc, geochemical, basement complex, cancer, mining

\section{Introduction}

Mining and related operations are the major anthropogenic source of heavy metal contamination which increases harmful metal content in the streams and negatively influence the environment. In Ibodi area of southwestern Nigeria, there is an intense artisanal mining operation going on which involves excavation of the alluvial soil (host rock) and washing away the waste directly into the stream. Heavy metals such as copper, zinc, cadmium, iron, arsenic, lead are been released into stream as a result of these mining activities it should be noted that uncontrolled direct dumping of mine tailings, domestic waste and discharge of domestic and industrial sewage water into the urban drainage systems are critical components of trace and heavy metal contamination (Tijani et al., 2004; Singh et al., 1990) especially in areas with lack of strict land-use plan and environmental protection regulations. Though sediments are said to represent the ultimate sinks for heavy metals in the environment (Gibbs et al., 1977), changing physico-chemical and environ-mental conditions may lead to remobilization and release of sediment-bound metal pollutants into the water column and consequently into the food chain system within an aquatic environment with serious health and environmental consequences. The environmental impact of mining includes erosion, formation of sinkholes, loss of biodiversity, and contamination of soil, groundwater and surface water by chemicals from mining processes. In some cases, additional forest logging is done in the vicinity of mines and chemicals like mercury, cyanide, sulphuric acid, arsenic and methyl mercury are used in various stages of mining; within the last quarter of the last century there were much interest on environmental pollution and in particular about geochemical distribution and fate of heavy metals in both water and sediment phases of urban drainage system. Though significant advances had been made in the developed regions of the world, there are still increasing concerns about the impacts of urbanization, agricultural, mining and industrial activities on drainage networks in the developing regions of the world, especially in areas with inadequate land use planning and proper waste disposal and management systems (Ajayi \& Mombeshora, 1990 ). This research work is to appraisal the various rock types within the study area and to investigate the geochemical assessment of major and trace element within the stream sediments of the study area with a view to elucidate any form or extent of pollution within the study area. The overall evaluation is expected to give an insight into vulnerability of urban drainage networks in a typical developing region in response to poor sanitation and waste disposal facilities and other anthropogenic activities within the populated urban catchment of a developing country. The study area covers Ibodi and its environment, Southwestern Nigeria. The area lies within latitude $7^{\circ} 33^{\prime} \mathrm{N}$ and $7^{\circ} 36^{\prime} \mathrm{N}$ and longitude $4^{\circ} 39^{\prime} \mathrm{E}$ and $4^{\circ} 42^{\prime}$ E other neighboring villages located within the studied area include Afon, Olorombo, Ile-oko, Ijano, Safari, Onigbogi, Isireyun, Oloyin, Aye-ile, and Iyemogun. The study area is easily accessible by complex road networks of major and minor roads as well as footpath linking one sampling point to the other (Figure 1) The climate is sub-humid tropical with average annual rainfall $1348.4 \mathrm{~mm}$. The area is well drained the common rivers in the study area include Isireyun and Ileki rivers the drainage pattern is dendritic.

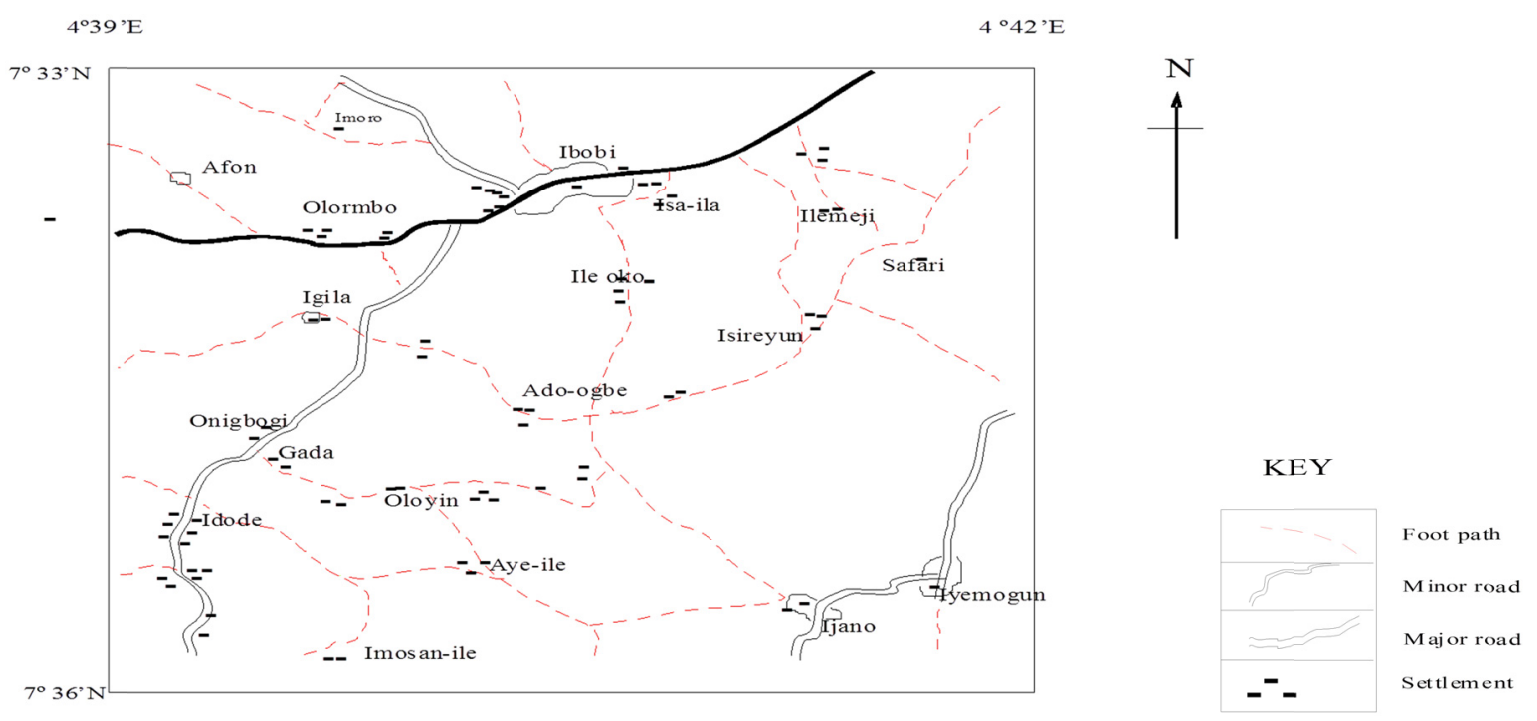

Figure 1. Map showing accessibility and location of the study area 


\section{Methodology of Study}

Systematic geological mapping and stream sediment sampling of first order streams in other to represent weathered rocks in the drainage system was carried out, followed by thin section Petrographic studies of fresh whole rock samples was carried out. Ten stream sediments samples were then analyzed for major and trace elements using inductively-coupled plasma atomic emission spectrophotometry (ICP-AES), at ACME Laboratory Vancouver Canada. The geochemical analytical procedure involves addition of $5 \mathrm{ml}$ of Perchloric acid $\left(\mathrm{HClO}_{4}\right)$, Trioxonitrate (V) $\mathrm{HNO}_{3}$ and $15 \mathrm{ml}$ Hydrofluoric acid (Hf) to $0.5 \mathrm{gm}$ of sample. The solution was stirred properly and allowed to evaporate to dryness after it was warmed at a low temperature for some hours. $4 \mathrm{ml}$ hydrochloric acid $(\mathrm{HCl})$ was then added to the cooled solution and warmed to dissolve the salts. The solution was cooled; and then diluted to $50 \mathrm{ml}$ with distilled water. The solution is then introduced into the ICP torch as aqueous - aerosol. The emitted light by the ions in the ICP was converted to an electrical signal by a photo multiplier in the spectrometer, the intensity of the electrical signal produced by emitted light from the ions were compared to a standard (a previously measured intensity of a known concentration of the elements) and the concentration then computed.

\section{Geological Setting, Field Description and Petrography}

Nigeria is underlain by Precambrian basement complex rocks, younger granites of Jurassic age and Cretaceous to Recent sediments. The basement rocks occupy about half of the land mass of the country, and is a part of the Pan-African mobile belt lying between the West African and Congo cratons (Black, 1980). There are however contrasting documentation of the evolution of the basement rocks. However loosely, the basement is grouped into three major groups lithostratigraphically viz: the Migmatite-Gneiss Quartzite Complex: comprising biotite and biotite hornblende gneisses, quartzites and quartz schist. Schist Belts, comprising paraschists and meta igneous rocks, which include schists, amphibolites, amphibole schists, talcose rocks, epidote rocks, marble and calc-silicate rocks. They are mainly N-S to NNE-SSW trending belts of low grade supracrustal (and minor volcanic) assemblages. Other secondary rocks used in delineating them are carbonates, calc gneiss and banded iron formation (BIF) and Older granites, which include granite, granodiorite, diorite charnockite, pegmatites and aplites. The study area is located within Ibodi, its geology consists of Precambrian rocks that are typical of Basement Complex of Nigeria and these rocks includes the following five lithologies: [i] Amphibolites [ii] Mica schist [iii] Granite gneiss [iv] Quartzite and [v] Talc (Figure 2).

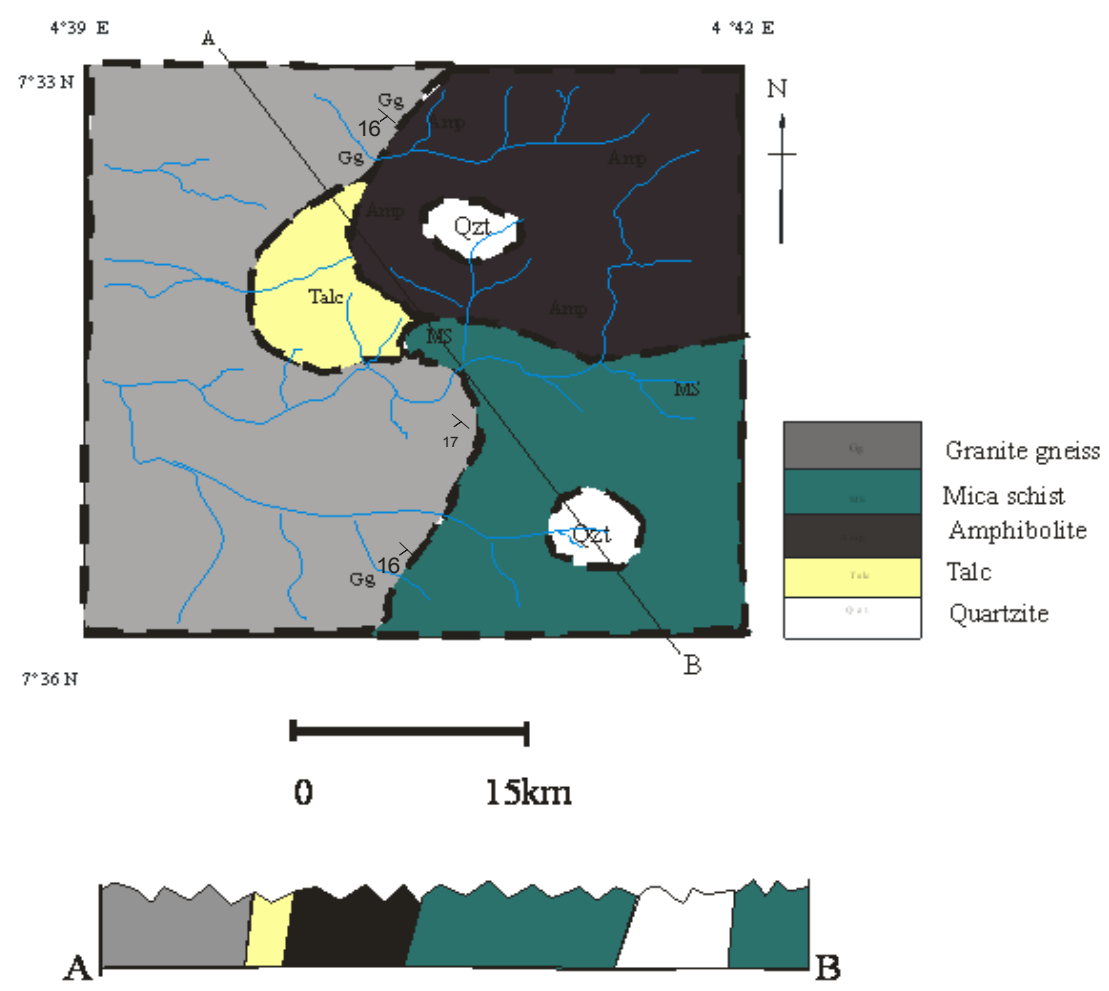

Figure 2. Geological map of Ibodi study area 


\section{Result and Discussion}

The analytical results of the major elements are presented in (Tables 1 and 2). Table 1, shows the major elements oxides composition of the Ibodi study area in $(\mathrm{Wt} \%)$ while Table 2 , shows the statistical summary of major elements oxides with their range and average values respectively. From the analytical data and the various statistical plots figure 5, shows the line diagrams of graphical illustration for major elements oxide composition in stream sediments of Ibodi study area. The analyses show that Iron oxide $\left[\mathrm{Fe}_{2} \mathrm{O}_{3}\right]$ has the highest major element composition with value ranging from $2.36 \%-10.61 \%$ with an average value of $5.262 \%$. This highest concentration of Iron oxide was found in location 1, with a value of $10.61 \%$. and this can be attributed to the underlying geology of amphibolites' in the Ibodi study area, which are known to be rich in Iron as well as magnesium i.e ferromagnesian minerals. Magnesium oxide [MgO] range in composition from $0.11 \%-0.92 \%$ with an average value of $0.349 \%$, the highest concentration was found in location 3. $\left[\mathrm{Al}_{2} \mathrm{O}_{3}\right]$ ranges in composition from $0.83 \%-4.158 \%$ with an average value of $2.109 \%$ the highest value was also found at location 3 , it is the next in abundance to Iron oxide in the Ibodi study area. Potassium oxide $\left[\mathrm{K}_{2} \mathrm{O}\right]$ range in composition from $0.04 \%-0.65 \%$ with an average value of $0.183 \%$, other major oxides such as $\left[\mathrm{P}_{2} \mathrm{O}_{5}\right]$, $\left[\mathrm{TiO}_{2}\right],\left[\mathrm{Na}_{2} \mathrm{O}\right]$ and $[\mathrm{CaO}]$ have average values of $0.109 \%, 0.096 \%, 0.008 \%$ and $0.162 \%$ respectively; These values are generally low within the Ibodi study area, (Figures 3 and 4) Show the 2D, 3D and geochemical maps of [Fe], [Ca], [Mn], [Ti] [Al], [K] and [Na] respectively within the study area. The correlation matrix (Table 3 ) shows a very strong and positive correlation of Ca-Fe, Mg-P, Ti-Mg, Na-Fe, S-Fe, S-Mg, S-Ti and S-Na with ' $r$ ' values of 0.854, 0.878, $0.893,0.820,0.942,0.832,0.906$ and 0.842 respectively; indicating that they are governed by the same geochemical factors and are from the same source. Also, the correlation matrix showed that Ti-Fe, Ti-P, Na-Ca, Na-Ti, K-Ca, K-P, and S-P with ' $r$ 'values of $0.697,0.682,0.528,0.637,0.547,0.601$ and 0.646 respectively, has strong and positive correlation, indicating that they are also governed by the same geochemical factors and they are from the same source, (Figure 6 ) shows the scatter plots for correlation matrix of major elements within the study area. The analytical results for trace element geochemistry of Ibodi study area are presented in (Tables 4 and 5). Table 4, shows the trace element concentrations of Ibodi study area in (ppm) and Table 5, shows the statistical summary of trace elements with their range and average values respectively. From these tables, Vanadium [V] has a high concentrations and it range from $35.00 \mathrm{ppm}-202.00 \mathrm{ppm}$ with an average mean value of $92.50 \mathrm{ppm}$, the highest concentration of this element was found in location 1 of the Ibodi study area. Arsenic [As] range from $0.10 \mathrm{ppm}-1.6$ $\mathrm{ppm}$ with an average value of $0.644 \mathrm{ppm}$, there is a significant enrichment of Cobalt [Co] and Chromium [Cr] with concentrations ranging from $4.0 \mathrm{ppm}-53.50 \mathrm{ppm}$ and $35.20 \mathrm{ppm}-150.70 \mathrm{ppm}$ respectively, with average mean values of $17.73 \mathrm{ppm}$ and $88.78 \mathrm{ppm}$ respectively; the 2D and 3D geochemical maps of [V], [As], [Co] and [Cr] are shown in (Figure 8a). Manganese [Mn] has the highest concentration in the study area, with concentration value ranging from $86.00 \mathrm{ppm}-2165.00 \mathrm{ppm}$ having an average value of $768.20 \mathrm{ppm}$; the highest concentration of this element was found in location 1 of the study area. [Ga], $[\mathrm{Ni}]$ and $[\mathrm{Pb}]$ show considerable enrichments within the study area with concentration values ranging from $3.10 \mathrm{ppm}-9.50 \mathrm{ppm}, 5.30 \mathrm{ppm}-37.70 \mathrm{ppm}$ and $6.75 \mathrm{ppm}-18.44$ ppm, with average values of $6.08 \mathrm{ppm}, 19.80 \mathrm{ppm}, 12.209 \mathrm{ppm}$ respectively, Figure 8b shows the 2D and 3D geochemical maps of [Ga], [Mn], [Ni] and [Pb] within the Ibodi study area. Rubidium [Rb] range in concentration from $6.50 \mathrm{ppm}-30.90 \mathrm{ppm}$ with an average value of $13.41 \mathrm{ppm}$, Strontium [Sr] has concentration values that range from $4.70 \mathrm{ppm}-37.20 \mathrm{ppm}$ with an average value of $15.06 \mathrm{ppm}$. [Y], [Zr] and [Zn] has concentration values that range from $7.99 \mathrm{ppm}-21.10 \mathrm{ppm}, 1.20 \mathrm{ppm}-4.00 \mathrm{ppm}$ and $26.20 \mathrm{ppm}-83.60 \mathrm{ppm}$ respectively with average mean values of $15.065 \mathrm{ppm}, 2.21 \mathrm{ppm}$ and $46.58 \mathrm{ppm}$, the value of zinc [Zn] is considerably high in the study area with the highest value found at location 4 of the study area indicating some level of enrichment of this metals within the study area, also [Rb], [Y] and [Sr] show some considerable enrichments within the study area as reflected in Figure 8c, which show the 2D and 3D geochemical maps of [Rb], [Sr], [Y], [Zn] and [Zr] in Ibodi study area; while Figure 7 show Pie charts of various concentrations of trace Elements within the Ibodi stream sediments. The geo-accumulation index (Igeo) is an environmental parameter that enables the assessment of contamination by means of comparism. It is used in relation to bottom sediment (Muller, 1969). It is computed using the formula: Igeo $=\log 2\left(\mathrm{Cn} / 1.5^{*} \mathrm{Bn}\right)$; Where $\mathrm{Cn}$ is the measured concentration of the elements. $\mathrm{Bn}$ is the normal or average shale content 1.5 is the correcting or matrix factor for geo-accumulation. The Igeo consist of seven grades (Table 6) ranging from practically uncontaminated to extremely contaminated (Muller, 1969). The geo-accumlation values of the selected trace elements in the stream sediment samples of Ibodi study area is shown in (Table 7). From the box plot and Geo-accumulation Table, (Figure 9; Table 7) respectively, the values of the selected trace elements are all less than 1, meaning that all the selected trace metals in Ibodi study area have values less than zero and are in the negative zone. In order to determine the pollution status of the study area, the values of the elements when compared to the Muller classes of geo-accumulation (1969), suggests that the study area is practically uncontaminated with the selected trace metals, the elements fall into the class 0 i.e. Practically unpolluted (Table 6) of Muller (1969). 
Table 1. Major Element Oxides Composition Of Ibodi Study Area (Wt \%)

\begin{tabular}{lllllllll}
\hline Location Nos & $\mathrm{Fe}_{2} \mathrm{O}_{3} \%$ & $\mathrm{CaO} \%$ & $\mathrm{P}_{2} \mathrm{O}_{5} \%$ & $\mathrm{MgO}_{0}$ & $\mathrm{TiO}_{2} \%$ & $\mathrm{Al}_{2} \mathrm{O}_{3} \%$ & $\mathrm{Na}_{2} \mathrm{O} \%$ & $\mathrm{~K}_{2} \mathrm{O} \%$ \\
\hline Loc 1 & 10.61775 & 0.15389 & 0.178932 & 0.2145 & 0.088457 & 2.3058 & 0.00536 & 0.08435 \\
Loc 2 & 4.15701 & 0.09793 & 0.066526 & 0.363 & 0.088457 & 2.457 & 0.0067 & 0.1205 \\
Loc 3 & 6.64092 & 0.15389 & 0.094054 & 0.924 & 0.163562 & 4.158 & 0.01608 & 0.6507 \\
Loc 4 & 2.59974 & 0.08394 & 0.032116 & 0.2475 & 0.085119 & 1.7955 & 0.00268 & 0.1446 \\
Loc 5 & 5.36679 & 0.22384 & 0.130758 & 0.3135 & 0.105147 & 2.1546 & 0.00536 & 0.1205 \\
Loc 6 & 2.36808 & 0.08394 & 0.04588 & 0.1155 & 0.086788 & 0.8316 & 0.00268 & 0.10845 \\
Loc 7 & 6.22908 & 0.18187 & 0.110112 & 0.132 & 0.068429 & 1.6065 & 0.00402 & 0.0482 \\
Loc 8 & 4.91634 & 0.26581 & 0.162874 & 0.495 & 0.113492 & 2.0223 & 0.00938 & 0.2169 \\
Loc 9 & 3.28185 & 0.1399 & 0.089466 & 0.264 & 0.08457 & 1.2285 & 0.0004 & 0.1205 \\
Loc 10 & 6.44787 & 0.23783 & 0.178932 & 0.429 & 0.076774 & 2.5326 & 0.0335 & 0.2169 \\
\hline
\end{tabular}

Table 2. Summary of Major Element in the Stream Sediment

\begin{tabular}{llllll}
\hline Elements & $\mathrm{N}$ & Minimum & Maximum & Mean & Std. Deviation \\
\hline $\mathrm{Fe}_{2} \mathrm{O}_{3}$ & 10 & 2.36 & 10.61 & 5.2625 & 2.44181 \\
$\mathrm{CaO}$ & 10 & 0.08 & 0.26 & 0.1623 & 0.06468 \\
$\mathrm{P}_{2} \mathrm{O}_{5}$ & 10 & 0.03 & 0.17 & 0.109 & 0.05319 \\
$\mathrm{MgO}$ & 10 & 0.11 & 0.92 & 0.3498 & 0.235 \\
$\mathrm{TiO}_{2}$ & 10 & 0.06 & 0.16 & 0.0961 & 0.02694 \\
$\mathrm{Al}_{2} \mathrm{O}_{3}$ & 10 & 0.83 & 4.15 & 2.1092 & 0.90093 \\
$\mathrm{Na}_{2} \mathrm{O}$ & 10 & 0.002 & 0.016 & 0.0086 & 0.00977 \\
$\mathrm{~K}_{2} \mathrm{O}$ & 10 & 0.04 & 0.65 & 0.1832 & 0.17246 \\
\hline
\end{tabular}

Table 3. Correlation Co-Efficients for Major Element Oxides

\begin{tabular}{|c|c|c|c|c|c|c|c|c|c|}
\hline & $\mathrm{Fe}$ & $\mathrm{Ca}$ & $\mathrm{P}$ & $\mathrm{Mg}$ & $\mathrm{Ti}$ & $\mathrm{Al}$ & $\mathrm{Na}$ & $\mathrm{K}$ & $\mathrm{S}$ \\
\hline $\mathrm{Fe}$ & 1 & & & & & & & & \\
\hline $\mathrm{Ca}$ & $0.854(* *)$ & 1 & & & & & & & \\
\hline $\mathrm{P}$ & 0.106 & -0.043 & 1 & & & & & & \\
\hline $\mathrm{Mg}$ & 0.360 & 0.069 & $0.878(* *)$ & 1 & & & & & \\
\hline $\mathrm{Ti}$ & $0.697(*)$ & 0.379 & $0.682\left(^{*}\right)$ & $0.893(* *)$ & 1 & & & & \\
\hline \multicolumn{10}{|l|}{$\mathrm{Al}$} \\
\hline & 0.359 & 0.465 & $-0.651(*)$ & -0.540 & -0.157 & 1 & & & \\
\hline $\mathrm{Na}$ & $0.820(* *)$ & 0.528 & 0.077 & 0.341 & $0.637\left(^{*}\right)$ & 0.400 & 1 & & \\
\hline K & 0.486 & 0.547 & 0.601 & 0.574 & 0.437 & -0.550 & 0.436 & 1 & \\
\hline S & 0.942 & 0.646 & 0.420 & 0.832 & 0.906 & 0.176 & 0.842 & 0.293 & 1 \\
\hline
\end{tabular}

Table 4. Trace Element Concentrations (ppm) in Stream Sediment of the Study Area

\begin{tabular}{|c|c|c|c|c|c|c|c|c|c|c|c|c|c|c|}
\hline & $\mathrm{V}(\mathrm{ppm})$ & $\mathrm{Cr}(\mathrm{ppm})$ & $\mathrm{Mn}(\mathrm{ppm})$ & Co (ppm) & $\mathrm{Ni}(\mathrm{ppm})$ & $\mathrm{Zn}(\mathrm{ppm})$ & $\mathrm{Ga}(\mathrm{ppm})$ & As (ppm) & $\mathrm{Se}(\mathrm{ppm})$ & $\mathrm{Rb}(\mathrm{ppm})$ & $\mathrm{Sr}(\mathrm{ppm})$ & $\mathrm{Y}(\mathrm{ppm})$ & $\mathrm{Zr}(\mathrm{ppm})$ & $\mathrm{Pb}(\mathrm{ppm})$ \\
\hline Loc 1 & 202.00 & 150.40 & 2165.00 & 53.50 & 37.70 & 65.10 & 9.10 & 1.60 & 0.20 & 8.80 & 37.20 & 11.74 & 2.90 & 17.31 \\
\hline $\operatorname{loc} 2$ & 96.00 & 62.20 & 181.00 & 10.70 & 17.70 & 65.10 & 7.70 & 0.30 & 0.10 & 10.30 & 29.40 & 12.94 & 1.90 & 17.31 \\
\hline $\operatorname{loc} 3$ & 120.00 & 100.30 & 1105.00 & 29.60 & 32.50 & 50.40 & 9.50 & 0.90 & 0.20 & 30.90 & 15.20 & 19.77 & 2.50 & 11.65 \\
\hline $\operatorname{loc} 4$ & 115.00 & 150.70 & 86.00 & 4.00 & 11.90 & 83.60 & 7.00 & $<0.10$ & $<0.10$ & 6.70 & 8.20 & 20.27 & 4.00 & 13.4 \\
\hline $\operatorname{loc} 5$ & 88.00 & 79.70 & 1550.00 & 24.60 & 24.20 & 26.20 & 6.30 & 1.10 & $<0.10$ & 10.80 & 12.10 & 14.59 & 2.40 & 14.22 \\
\hline $\operatorname{loc} 6$ & 35.00 & 35.20 & 381.00 & 8.40 & 5.30 & 42.60 & 3.10 & 0.30 & $<0.10$ & 10.50 & 4.70 & 7.99 & 1.20 & 9.69 \\
\hline $\operatorname{loc} 7$ & 95.00 & 92.40 & 561.00 & 15.30 & 14.20 & 28.00 & 5.80 & 1.10 & 0.10 & 6.50 & 13.70 & 10.83 & 2.20 & 6.75 \\
\hline $\operatorname{loc} 8$ & 85.00 & 82.50 & 1292.00 & 21.80 & 22.40 & 41.70 & 5.30 & 0.70 & 0.10 & 16.70 & 18.90 & 11.05 & 2.30 & 18.44 \\
\hline $\operatorname{loc} 9$ & 59.00 & 55.00 & 748.00 & 17.10 & 15.20 & 37.80 & 3.90 & 0.20 & $<0.10$ & 10.90 & 12.40 & 11.01 & 1.40 & 9.72 \\
\hline $\operatorname{loc} 10$ & 116.00 & 114.90 & 889.00 & 22.90 & 27.30 & 39.00 & 6.10 & 0.60 & $<0.10$ & 15.40 & 18.00 & 21.10 & 2.10 & 10.63 \\
\hline
\end{tabular}


Table 5. Summary of Selected Trace Elements Concentration of Stream Sediments

\begin{tabular}{llllll}
\hline Elements & $\mathrm{N}$ & Minimum & Maximum & Mean & Std. Deviation \\
\hline $\mathrm{V}$ & 10 & 35.00 & 202.00 & 92.50 & 27.6697 \\
$\mathrm{Cr}$ & 10 & 35.20 & 150.70 & 88.78 & 33.6398 \\
$\mathrm{Mn}$ & 10 & 86.00 & 2165.00 & 768.20 & 475.121 \\
$\mathrm{Co}$ & 10 & 4.00 & 53.50 & 17.73 & 8.09253 \\
$\mathrm{Ni}$ & 10 & 5.30 & 37.70 & 19.80 & 8.36328 \\
$\mathrm{Zn}$ & 10 & 26.20 & 83.60 & 46.58 & 17.2757 \\
$\mathrm{Ga}$ & 10 & 3.10 & 9.50 & 6.08 & 1.81157 \\
$\mathrm{As}$ & 9 & 0.10 & 1.60 & 0.6444 & 0.33953 \\
$\mathrm{Se}$ & 4 & 0.10 & 0.20 & 0.125 & 0.05 \\
$\mathrm{Rb}$ & 10 & 6.50 & 30.90 & 13.41 & 7.0606 \\
$\mathrm{Sr}$ & 10 & 4.70 & 37.20 & 15.06 & 6.74754 \\
$\mathrm{Y}$ & 10 & 7.99 & 21.10 & 15.065 & 5.02623 \\
$\mathrm{Zr}$ & 10 & 1.20 & 4.00 & 2.21 & 0.75491 \\
$\mathrm{~Pb}$ & 10 & 6.75 & 18.44 & 12.209 & 3.63893 \\
\hline
\end{tabular}

Table 6. Geo-Accumulation Index Classes (Muller 1981)

\begin{tabular}{lll}
\hline Igeo class & Values & Sediment quality \\
\hline 0 & Igeo $<0$ & Practically uncontaminated \\
1 & $0<$ Igeo $<1$ & Uncontaminated to moderately contaminate \\
2 & $1<$ Igeo $<2$ & Moderately contaminated \\
3 & $2<$ Igeo $<3$ & Moderately to heavily contaminated \\
4 & $3<$ Igeo $<4$ & Heavily contaminated \\
5 & $4<$ Igeo $<5$ & Heavily to extremely contaminated \\
6 & $5<$ Igeo $<6$ & Extremely contaminated \\
\hline
\end{tabular}

Table 7. Geo-Accumulation Distribution of the Elements Against the Locations

\begin{tabular}{lllllllllll}
\hline & $\mathrm{As}$ & $\mathrm{Co}$ & $\mathrm{Ce}$ & $\mathrm{Sb}$ & $\mathrm{Mn}$ & $\mathrm{Mo}$ & $\mathrm{Se}$ & $\mathrm{Zn}$ & $\mathrm{Pb}$ & $\mathrm{Ni}$ \\
\hline L1 & -2.90689 & -2.90689 & -3.90689 & -4.90689 & -2.20645 & -4.71425 & -3.90689 & -7.22882 & -1.58496 & -6.71425 \\
L2 & -3.90689 & -2.90689 & -3.90689 & -3.90689 & -1.44746 & -5.71425 & -3.90689 & -7.81378 & -1.58496 & -6.71425 \\
L3 & -3.90689 & -2.90689 & -2.90689 & -4.90689 & -1.58496 & -5.71425 & -2.90689 & -7.22882 & -1.09954 & 0 \\
L4 & -3.90689 & -2.90689 & -3.90689 & -3.32193 & -2.20645 & -5.12928 & -2.90689 & -7.22882 & -1.58496 & -6.71425 \\
L5 & -3.90689 & -1.90689 & -3.90689 & -3.90689 & -2 & -5.12928 & -3.90689 & -7.81378 & -1.09954 & -6.71425 \\
L6 & -3.90689 & -1.32193 & -2.90689 & -3.90689 & -2 & -4.71425 & -3.90689 & -6.81378 & -1.09954 & 0 \\
L7 & -2.32193 & -2.90689 & -2.32193 & -3.90689 & -2.20645 & -6.71425 & -3.90689 & -6.22882 & -1.09954 & -6.71425 \\
L8 & -3.90689 & -1.90689 & -3.90689 & -4.90689 & -1.58496 & -5.71425 & -2.90689 & -7.22882 & -0.90689 & 0 \\
L9 & -3.90689 & -2.32193 & -3.90689 & -3.90689 & -1.44746 & -5.71425 & -2.32193 & -6.81378 & -1.09954 & -6.71425 \\
L10 & -3.90689 & -2.90689 & -3.90689 & -3.90689 & -1.44746 & -5.12928 & -3.90689 & -7.81378 & -1.58496 & 0 \\
\hline
\end{tabular}



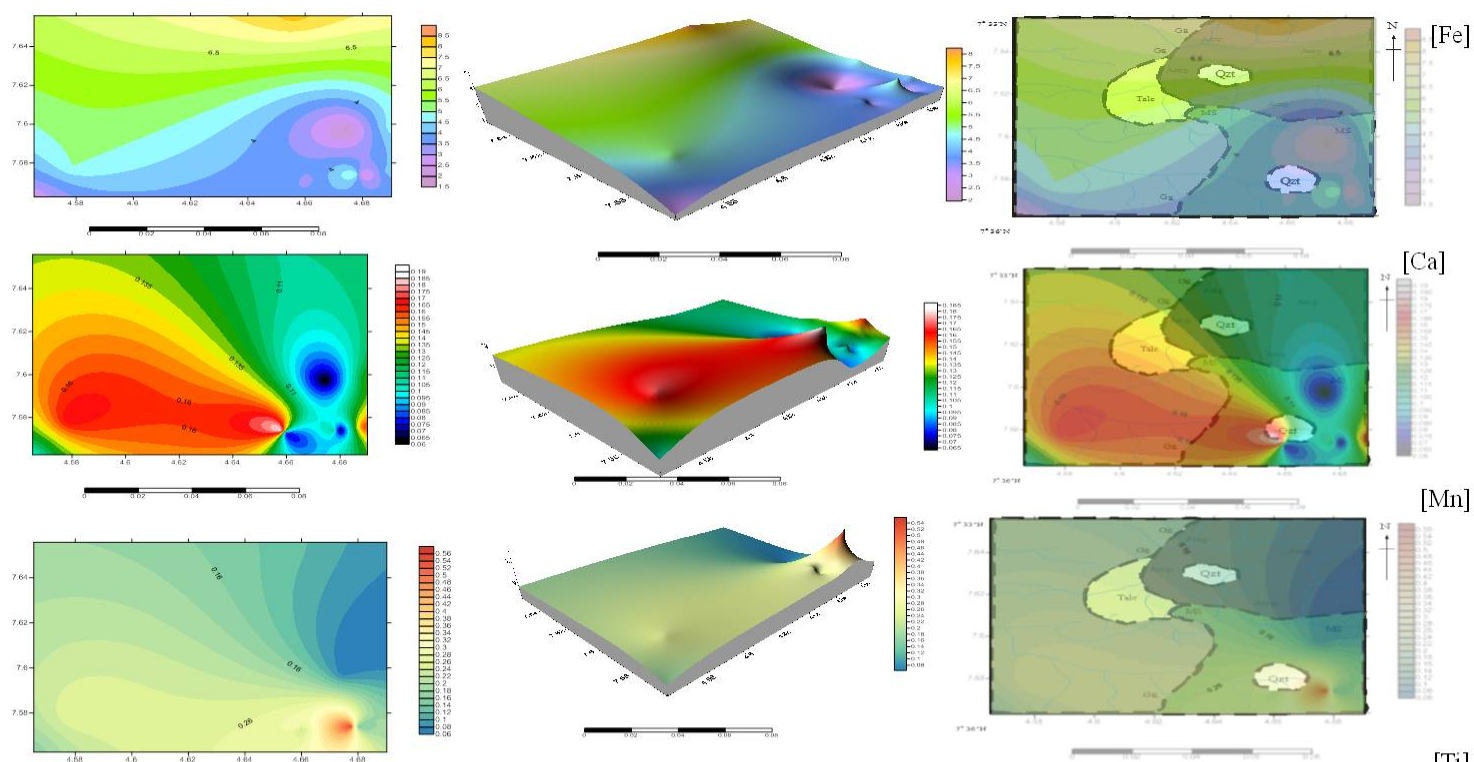

[Mn]
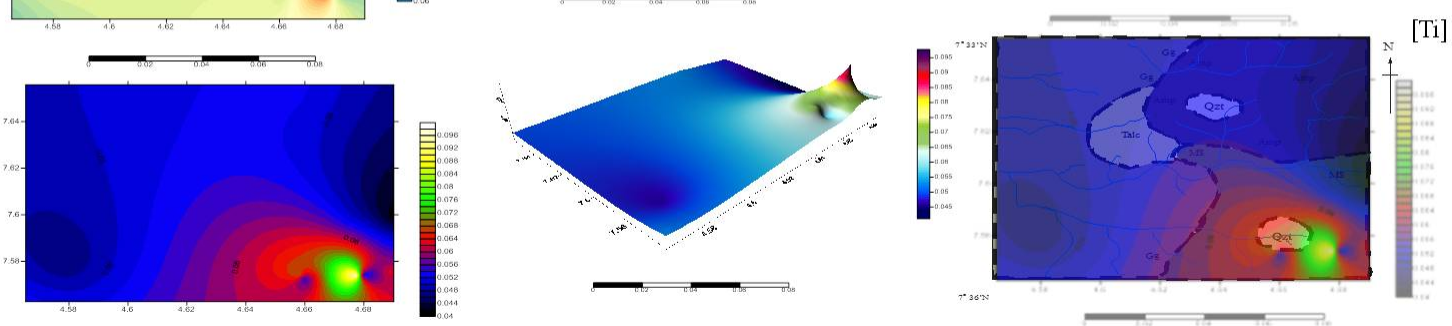

Figure 3. Showing 2D, 3D and geochemical maps of [Fe], [Ca], [Mn] and [Ti] respectively
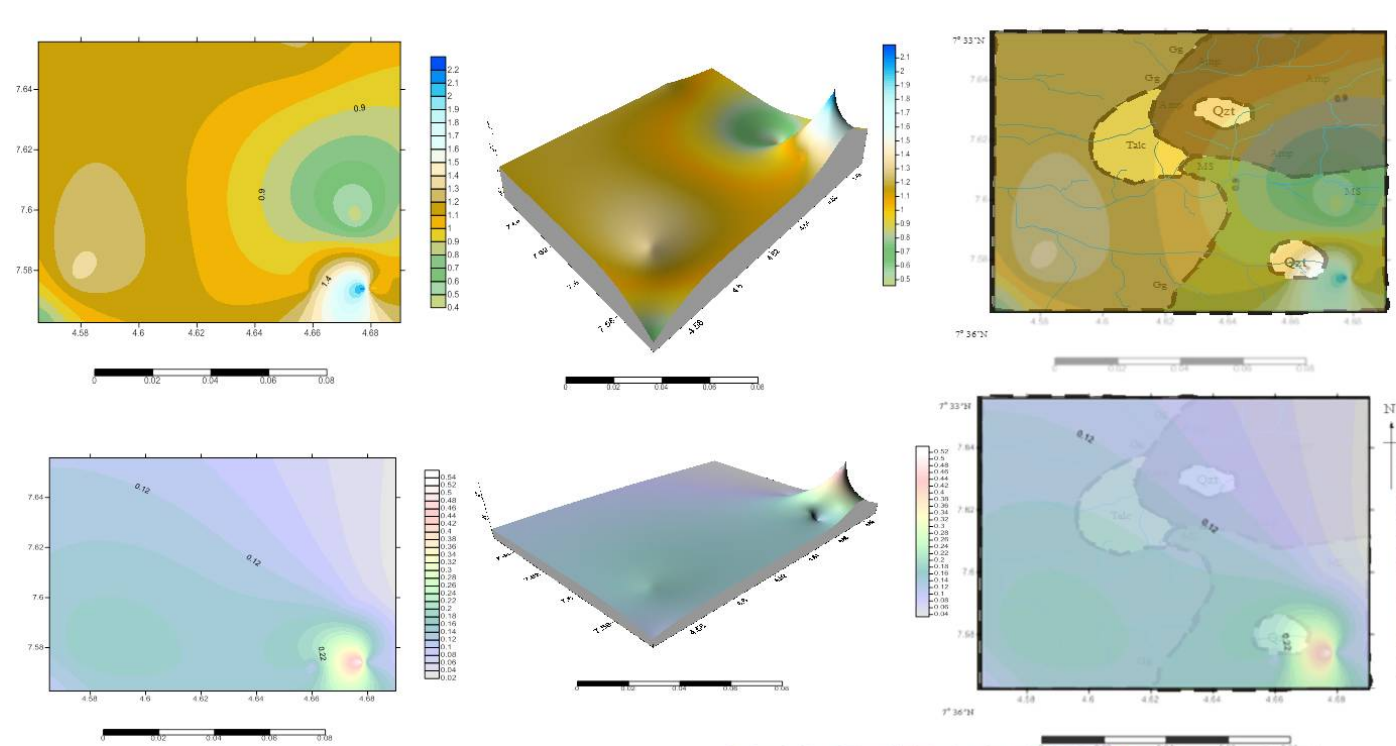

$[\mathrm{K}]$
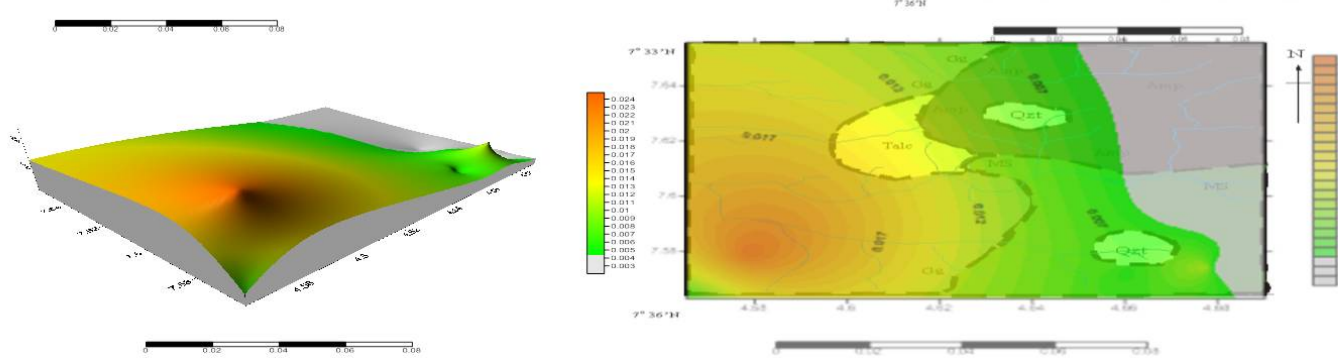

[Na]

Figure 4. Showing 2D, 3D and geochemical maps of [Al], [K] and [Na]respectively 

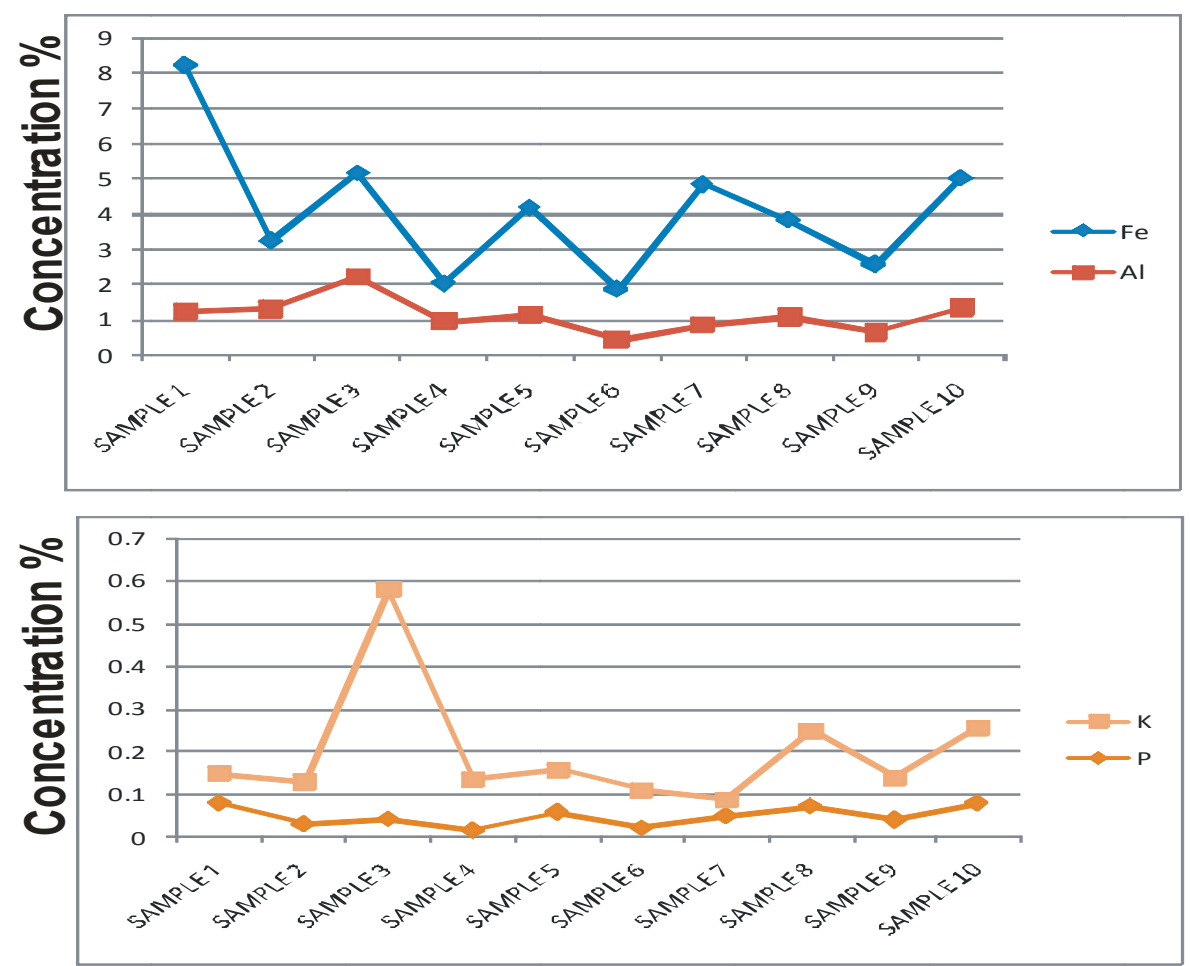

Figure 5. Line diagrams showing Descriptive Statistics of major Concentration in Stream Sediments around the Study Area
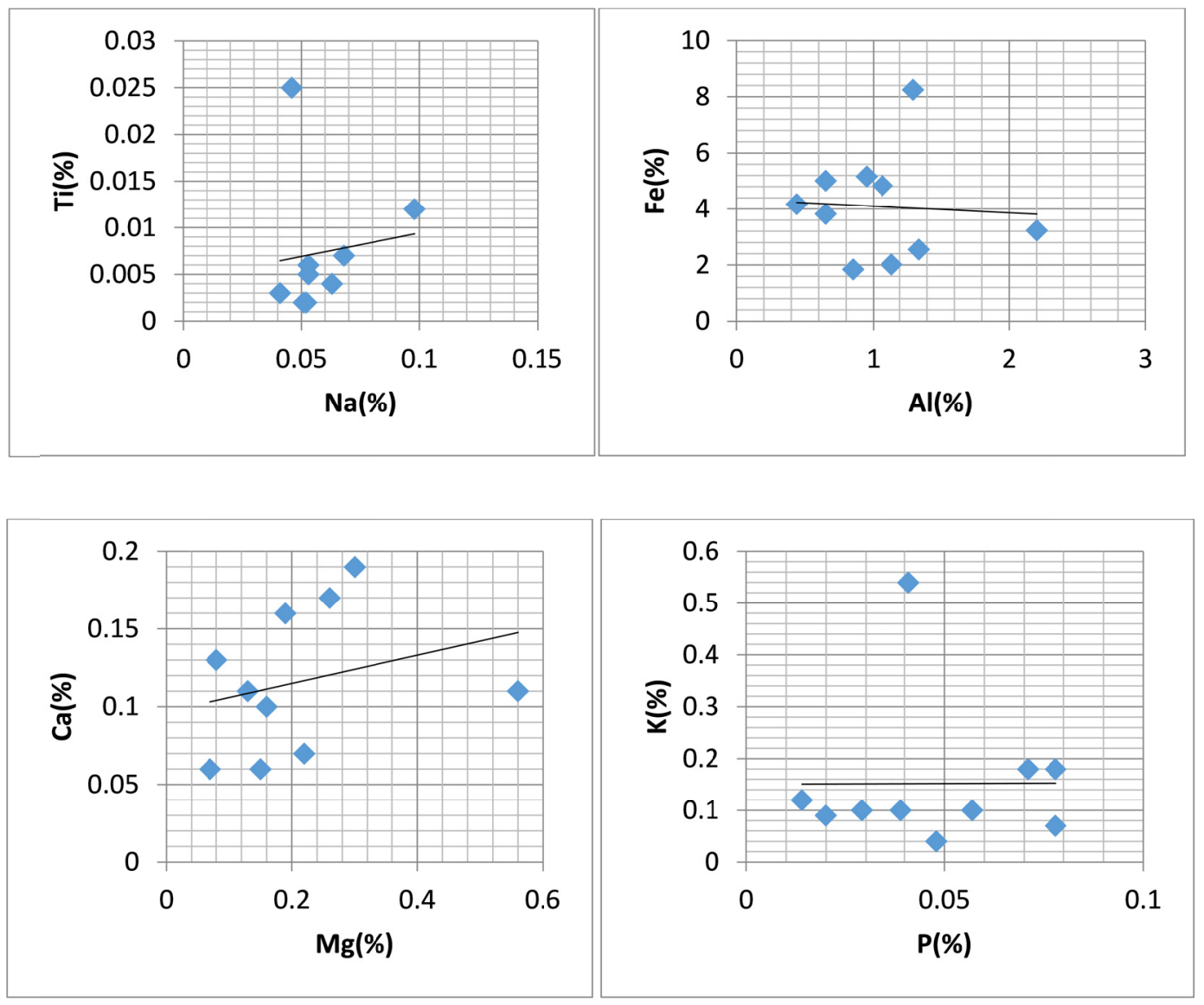

Figure 6. Scatter plots for correlation matrix of major element 

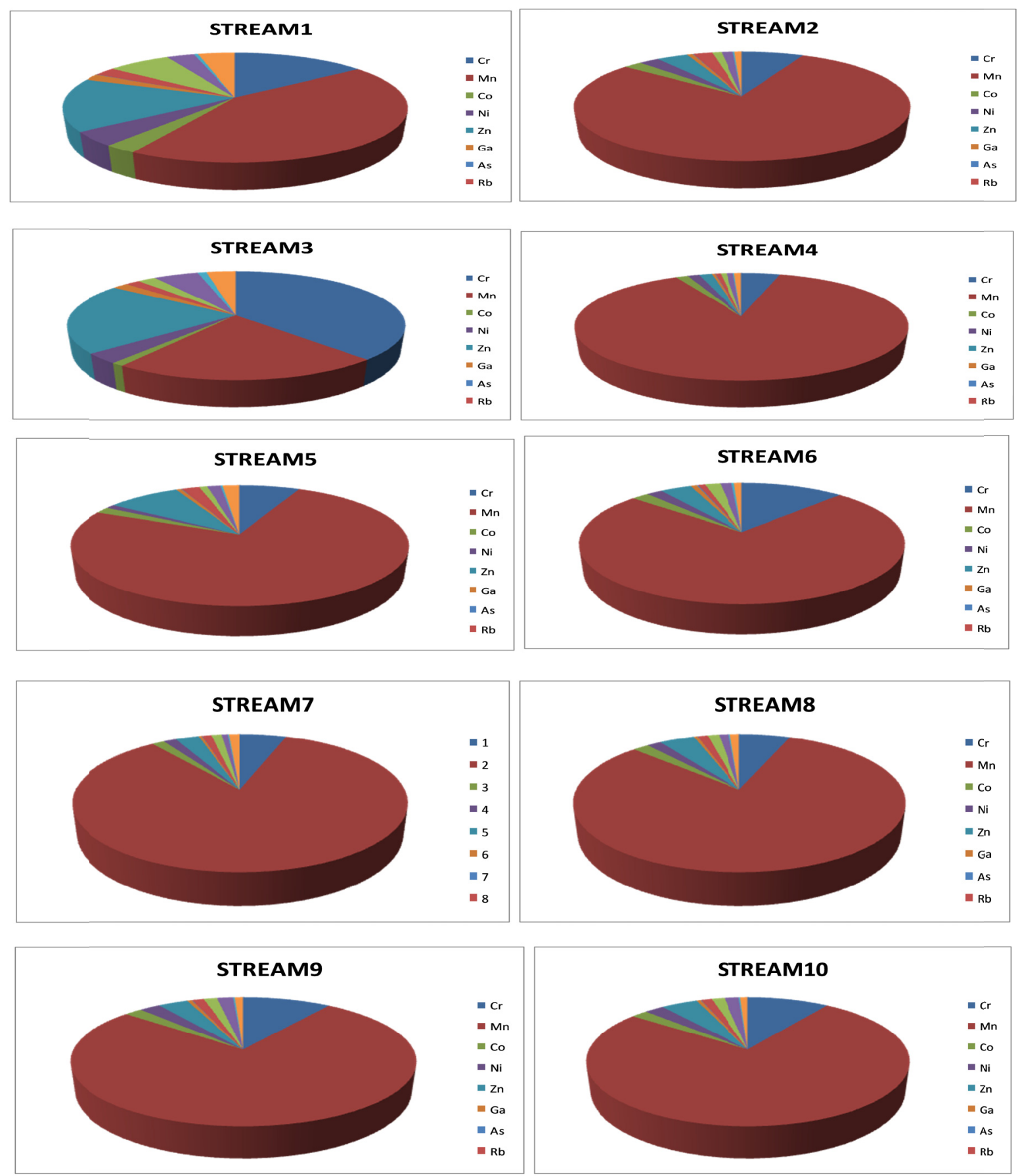

Figure 7. Pie charts showing various concentration of trace Elements within the Ibodi stream sediments 

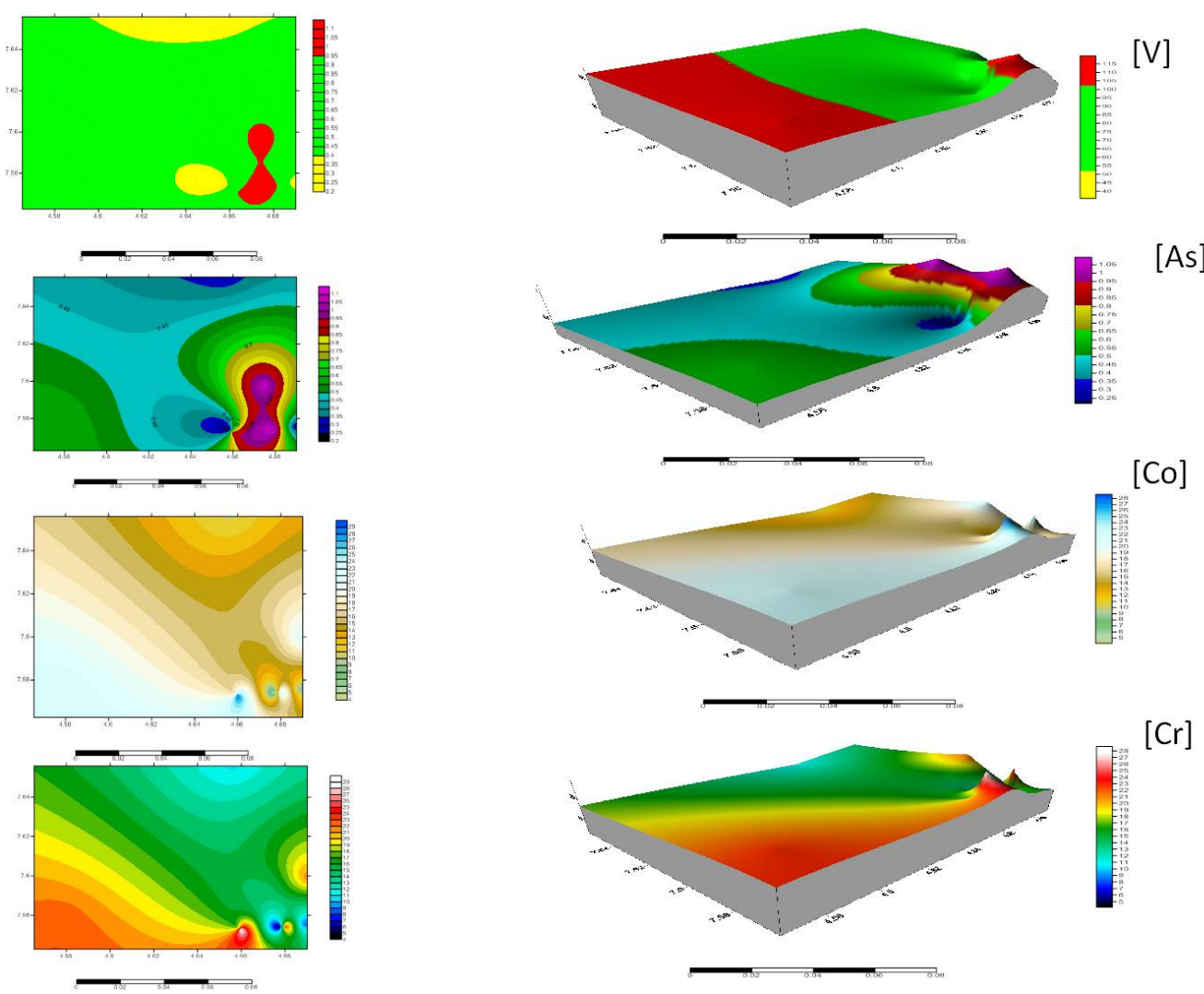

[As]

Figure $8 \mathrm{a}$. showing 2D and 3D geochemical maps of [V], [As], [Co] and [Cr] respectively
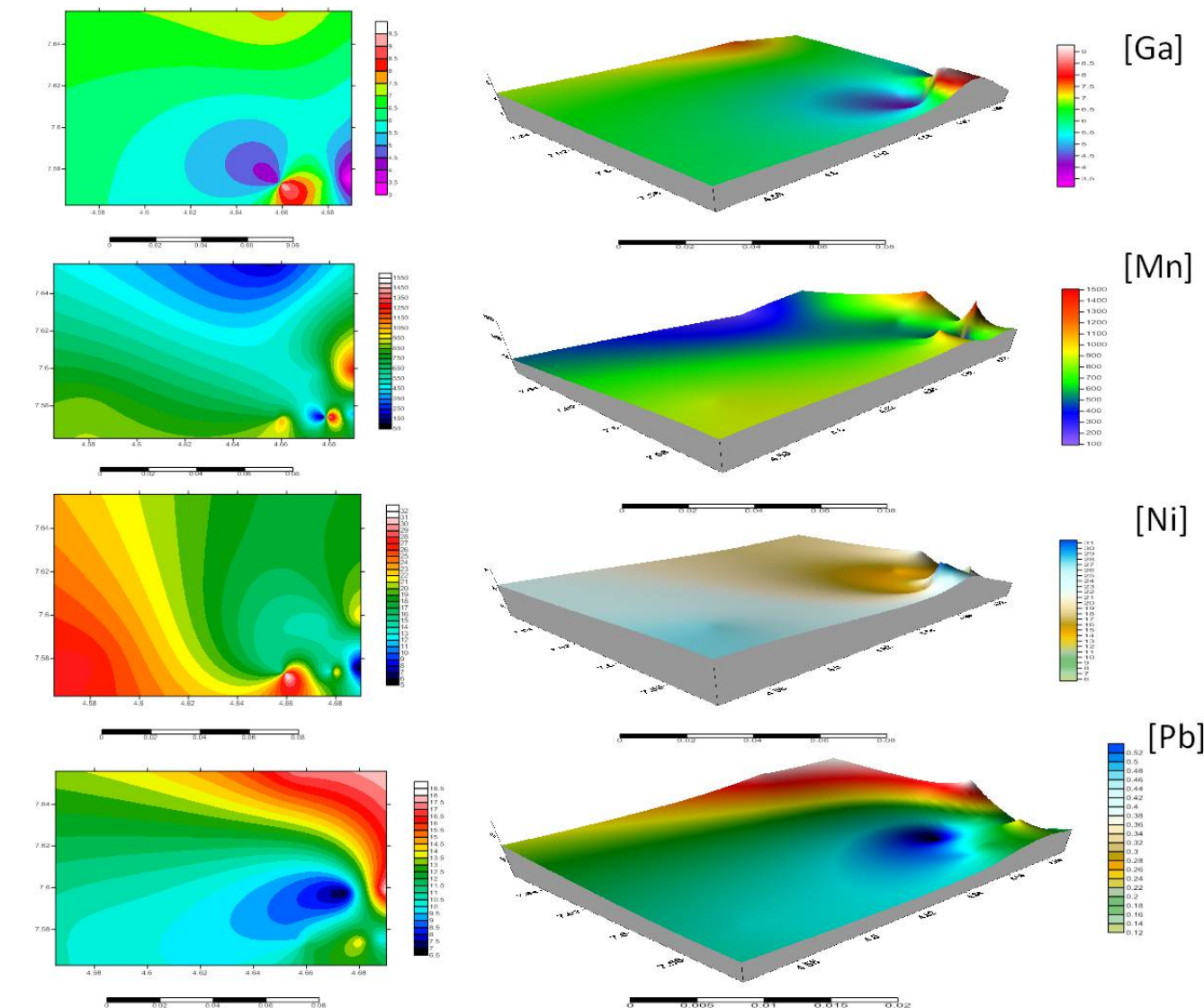

$[\mathrm{Ni}]$

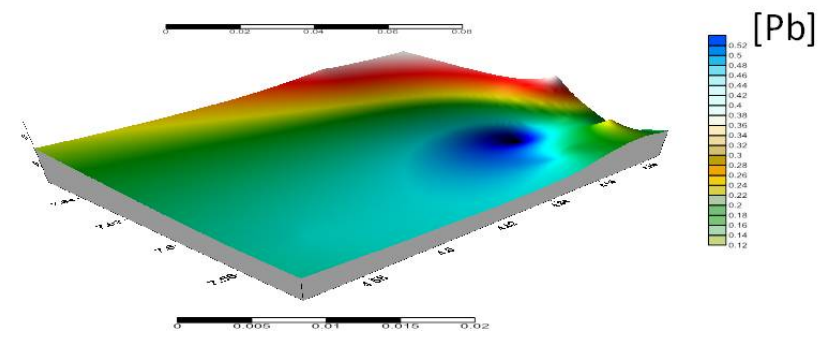

Figure $8 b$. showing 2D and 3D geochemical maps of [Ga], [Mn], [Ni] and [Pb] respectively 

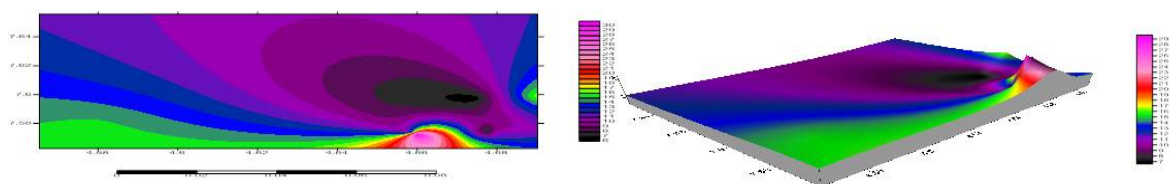

$[\mathrm{Rb}]$
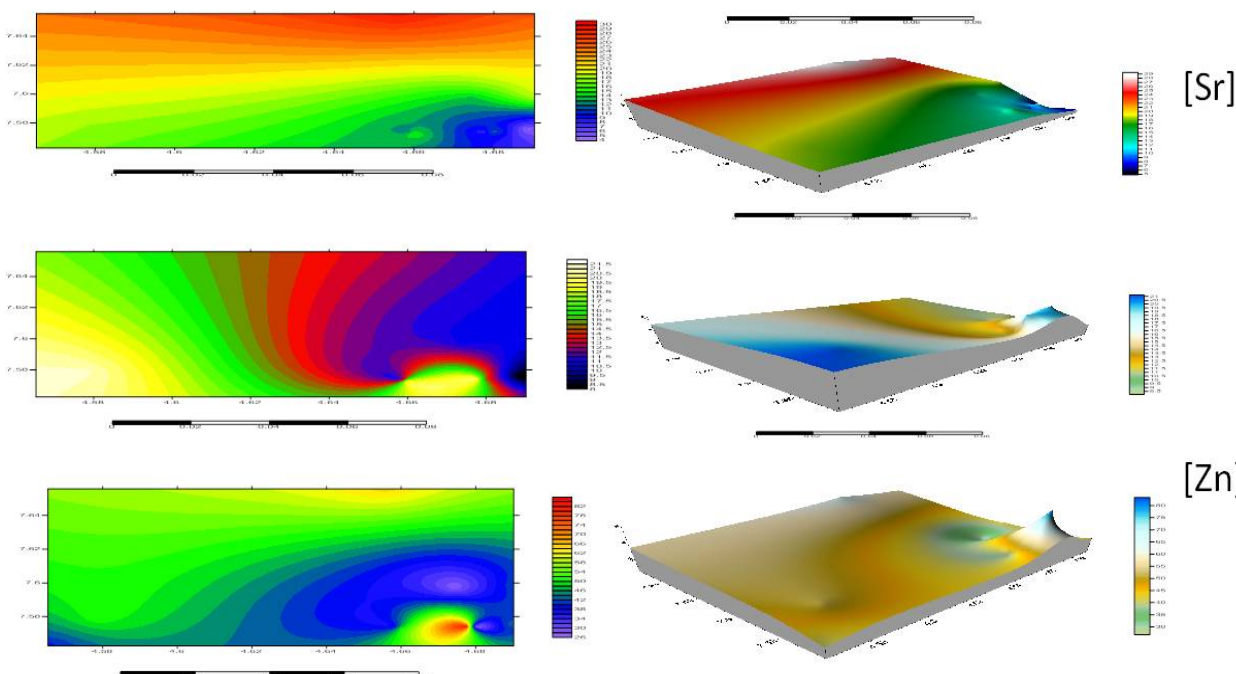

$[\mathrm{Zn}]$
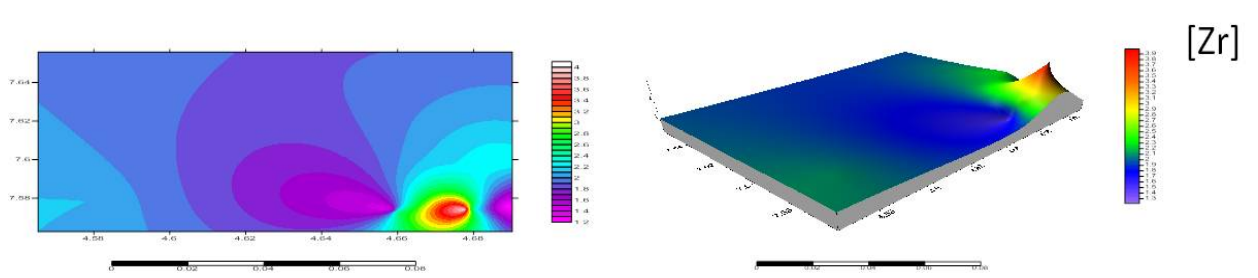

Figure 8c. showing 2D and 3D geochemical maps of [Rb], [Sr], [Y], [Zn] and [Zr] respectively

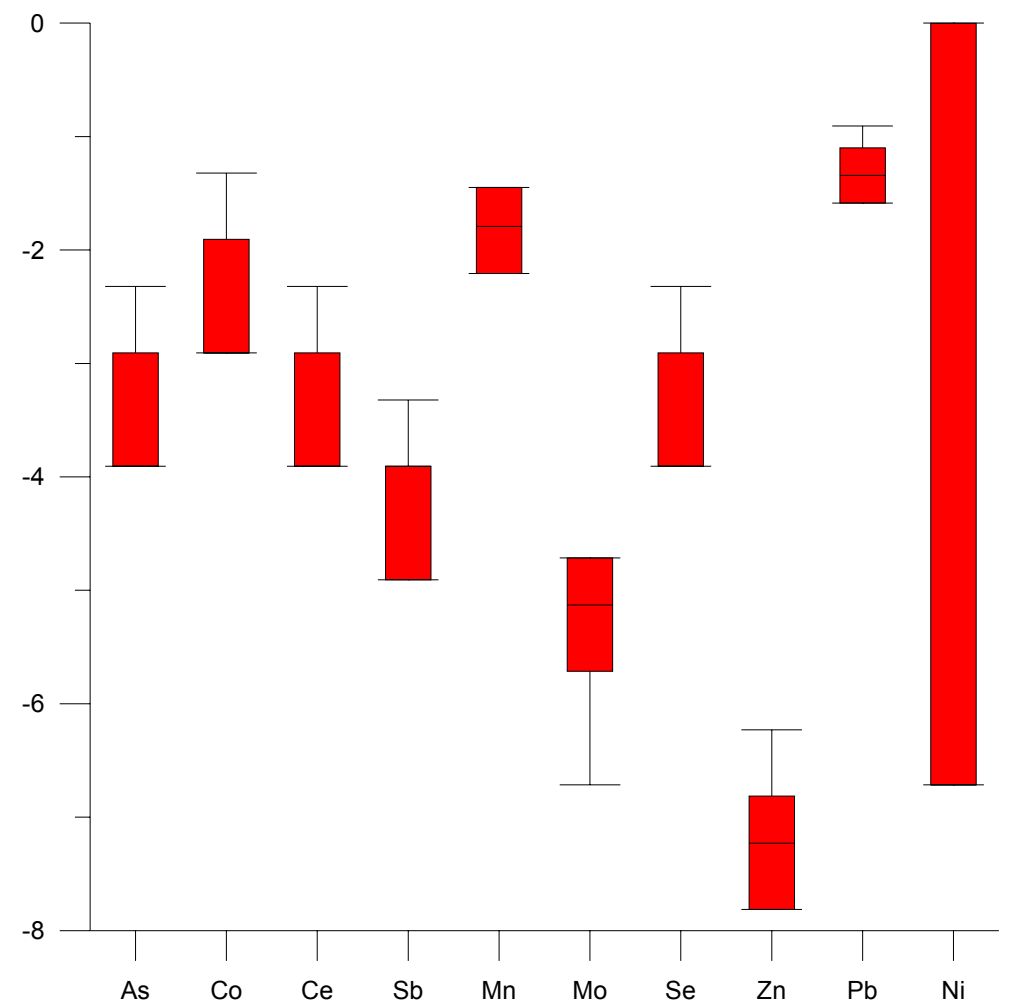

Figure 9. Box plot showing the geo-accumulation index of the selected trace elements 


\section{Conclusion}

The study area is characterized by lithologies such as Amphibolites, Mica schist, Granite gneiss, Quartzite and Talc they are Precambrian rocks that are typical of the Basement Complex of Nigeria. The result of major elements concentration shows that there are natural concentrations of Major elements such as $[\mathrm{Fe}],[\mathrm{Mg}],[\mathrm{Al}],[\mathrm{K}],[\mathrm{Ti}]$, $[\mathrm{Na}]$ and $[\mathrm{Ca}]$ in some locations within the study area which indicates abundance of Ferro-magnesia and Al-rich minerals present in the Amphibolite and other rocks in the study area. Also the trace element geochemistry shows the various concentrations of trace elements [V], [As], [Co]. [Cr], [Ga], [Mn], [Ni], [Pb], [Rb], [Sr], [Y], [Zn], $[\mathrm{Zr}]$ in the study area. The result of the correlation co-efficient suggests a common source between these elements. It can be inferred from the geo-accumulation index which is an environmental parameter that enables the assessment of contamination by means of comparism that result from the Ibodi study area has proven that values of selected trace elements are all less than 1, meaning that all the trace metals in Ibodi study area have values less than zero and are in the negative zone suggesting that the study area is practically uncontaminated with the selected trace metals with the elements falling into the class of 0 'Practically uncontaminated' according to Muller, 1969. The result has clearly shown the level of uncontamination in the area under investigation. It is therefore suggested that regular geochemical research work should be carried out in this study area to determine future rise in contamination level as a result of mining activities going on in this environment in addition; Mining activities in the area should be controlled to minimize the amount of pollutants released into the streams and water bodies within the study area in other to guide against health hazards caused by high concentrations of some of these metals on both man and animals.

\section{Acknowledgement}

The authors acknowledge the assistance of Mr Mafoluku, chief technologist of the Department of Geology University of Ibadan for his cooperation during the production of the thin section slides for petro graphic studies, in addition Dr Okunlola Olugbenga of the Department of Geology University of Ibadan is also highly appreciated for his numerous support.

\section{References}

Ajayi, S. O, Mombeshora, C., \& Osibanjo, O. (1990). Pollution studies on Nigerian rivers: The onset of lead pollution of surface waters in Ibadan. Int. Journal on Environ. Science, 9, 81-92

Black, R. (1980). Precambrian of west Africa Episode, 4, 3-8

Gibbs, A., Bruce, R., George, C., Bacuta jr, A., Robert, W., Kay, A., \& Allan, K. (1977). Platinum - group element abundance distribution in chromite deposits of the Acoje block, Zambales Ophiolite complex, Philippines. Journal of geochemical exploration, 37(1), 113-145

Muller, G. (1969). Index of Geoaccumulation in sediments of Rhine River. Geol. J., 2, 108-118

Singh, M., Ansari, A. A., Muller, G., \& Singh, I. B. (1990). Heavy metals in freshly deposited sediments of Gomatti River (A tributary of gange river), effect of human activities. Environ. Geol., 29(3), 246-252.

Tijani, M. N, Jinno, K., \& Hiroshiro, Y. (2004). Environmental impact of Heavy metal distribution in water and sediments of Ogunpa River Ibadan Area, southwestern Nigeria. Journal of Mining and Geology, 40(1), 73-83. http://dx.doi.org/10.4314/jmg.v40i1.18811

\section{Copyrights}

Copyright for this article is retained by the author(s), with first publication rights granted to the journal.

This is an open-access article distributed under the terms and conditions of the Creative Commons Attribution license (http://creativecommons.org/licenses/by/3.0/). 